Marjeta Potrč

direktorica

kadrovsko-

pravnega sektorja $v$

tovarni zdravil

Krka

\title{
KAKO IZBOLJŠATI IZOBRAZBENO STRUKTURO ZAPOSLENIH?
}

\section{Komentarji $k$ nekaterim trditvam in predlogom $\checkmark$ raziskavah o visokošolskem izobraževanju odraslih}

V

Krki smo bili še posebej pozorni do pregleda poglavitnih problemov in do predlogov ter priporočil $\mathrm{v}$ zvezi $\mathrm{z}$ visokošolskim izobraževanjem odraslih.

Menimo, da lahko s stališča delodajalcev in zaposlenih $\mathrm{v}$ celoti podpremo poglavitne probleme in tudi predloge ter priporočila $\mathrm{v}$ zvezi $\mathrm{z}$ visokošolskim izobraževanjem odraslih.

$V$ nadaljevanju bom predstavila naše mnenje o posameznih trditvah in naša prizadevanja za spremembo oziroma ureditev razmer, pri nekaterih točkah pa naše predloge oziroma dopolnitve v zvezi z že predlaganim.

Ker nas je ob prebiranju gradiva motil izraz »zaposlovalec«, čeprav je pojasnjeno, da pomeni podjetja in organizacije, bomo uporabljali raje izraz delodajalec, ki se je v zadnjih nekaj letih že močno uveljavil, določen pa je tudi $s$ predpisi in večinoma je jasno, koga predstavlja.

\section{PROBLEMI IN POTREBE DELODAJALCEV}

- Nejasna kadrovsko-izobraževalna usmeritev večine podjetij (starih, novih, večjih, manjših) in zavodov v zvezi s spremembami (prestrukturiranje, lastninjenje itn.).

Ta trditev popolnoma drži. Kako to izvajamo v Krki, je navedeno v nadaljevanju, vendar v tem delu omenjamo le projekcijo potreb po kadrih.

Stalna skrb naše kadrovske politike je izboljšanje izobrazbene strukture zaposlenih. Iz podatkov izhaja, da to tudi nenehno uresničuje- mo. Glede na izobrazbeno strukturo je opazno upadanje števila zaposlenih $\mathrm{z}$ nižjo izobrazbo, z 18 odstotkov v letu 1992 se je namreč znižalo na 12 odstotkov v letu 1996. Pri delavcih s srednjo in višjo izobrazbo je očitno rahlo povečevanje zaposlenosti. Najbolj se zvišuje izobrazbena raven zaposlenih $\mathrm{z}$ visoko izobrazbo, s 16 odstotkov v letu 1992 se je v letu 1996 namreč zvišala na 22 odstotkov, in sicer $\mathrm{v}$ osnovni dejavnosti Krke, doma in $\mathrm{v}$ tujini. Po kadrovski projekciji do leta 2000, ki jo dosledno uresničujemo, bo leta 2000 znašala 30 odstotkov.

Do leta 1991 se je prodaja v Krki nenehno povečevala, z osamosvojitvijo Slovenije, izgubo jugoslovanskega trga in razpadom Sovjetske zveze pa se je zmanjšala.

V letu 1993 smo oblikovali jasno strategijo razvoja podjetja do leta 2000 . Zato je razvojni odbor zahteval, da pripravimo tudi projekcijo potreb po visokostrokovnih delavcih do leta 2000. Osnova zanjo je bila analiza sedanjega kadra glede na poklicno in starostno strukturo ter ocena potreb glede na razvojno strategijo podjetja, širjenje mreže $v$ tujini, investicijska vlaganja, predvidene tehnološke in tehnične spremembe ipd.

Glede na dejavnosti bomo potrebovali največ visokostrokovnih delavcev pri razvoju in raziskavah ter $\mathrm{v}$ marketingu in prodaji. Skupaj jih je bilo 442, od tega 248 v Sloveniji in 194 $\mathrm{v}$ tujini.

Zelo je zanimiva poklicna struktura potrebnih novozaposlenih delavcev, ki je skoraj enaka poklicni strukturi že zaposlenih viso- 
kostrokovnih delavcev. V Sloveniji jih potrebujemo 248 , od tega $\vee$ farmaciji/kemiji 77 , kemiji/kemijski tehnologiji 64, ekonomiji 32, medicini 26 , veterini 9 , strojništvu 8 , elektrotehniki (šibki tok)7, računalništvu 6 in drugje 19, v tujini pa 194, torej skupaj 442.

Tudi nam, ki se v Krki že zelo dolgo ukvarjamo s kadrovskim področjem, so se zdele zahteve izjemno visoke. Vendar nam podatki za zadnja tri leta (načrt in njegova uresničitev) dokazujejo, da bo dinamika novega zaposlovanja v prvih letih tega obdobja celo izrazitejša, kot je bila načrtovana.

V letošnjem letu pa smo pripravili projekcijo potreb po kadrih do leta 2005. Preveritev projekcije za obdobje 1997-2000 kaže podvojitev potreb po visokostrokovnih delavcih, ocena za obdobje 2001-2005 pa kaže umiritev zaposlovanja visokostrokovnih kadrov na približno 27 vsako leto. V tem obdobju pričakujemo tudi izrazitejše upokojevanje visokostrokovnih kadrov.

Delodajalei bi morali imeti izdelano jasno projekcijo potreb po kadrih. Taki podatki so zelo pomembni za pravočasno iskanje ustreznih virov kadrov. Seveda bi lahko iz takih podatkov, če bi jih sistematično zbirali vsi delodajalci, država oziroma ustrezne institucije dolgoročneje uvajale nove študijske programe, širile ali ožile število vpisnih mest ipd.

- Slabo poznavanje in podpiranje individualnih potreb po izobraževanju, tudi »ilegalni « študij samoplačnikov ni redek.

V sklopu projekta razvoja kadrov na osnovi potreb podjetja ter posameznikovih sposobnosti in želja, na podlagi temeljnih usmeritev neposrednega vodje in direktorja sektorja izdelamo delavčev razvojni in izobraževalni načrt. V njem opredelimo njegove razvojne možnosti, v okviru katerih določimo, kam bomo usmerili njegov razvoj - v vodenje, stroko ali neko vmesno kombinacijo (na primer: projektno vodenje). Opredelimo tudi to, koliko časa in izkušenj je potrebnih, da lahko posameznik prevzame odgovornejše naloge. Ker se organizacijska struktura pogosto spreminja, je nemogoče načrtovati delovna mesta. Zato smo se odločili, da v razvojnem načrtu opredelimo področje dela, kjer naj bi delavec delal. Načrtovanim usmeritvam in posame- znikovim razvojnim možnostim prilagodimo izobraževalni načrt, ki ne vsebuje samo znanja, potrebnega za uspešno opravljanje sedanjega in prihodnjega dela, temveč upoštevamo tudi osebne želje, saj vemo, da je za poklicni razvoj potreben tudi osebni razvoj. Razvojni načrt predvideva nenehen razvoj posameznika kot osebnosti, strokovnjaka, vodje in skupinskega delavca.

Kljub načrtnemu delu v zvezi z razvojem kadrov pa tudi v $\mathrm{Kr}$ ki obstajajo posamezniki, »ile-

Razvoj kadrov zahteva izdelavo razvojnega in izobraževalnega načrta za posameznega delavca. galni « študenti. Razlog za to je večinoma premajhno samozaupanje, ker marsikdo zaradi bojazni, da bo pri študiju neuspešen ne zaprosi za ugodnosti v zvezi s študijem, dokler se sam ne prepriča, da bo lahko uspešno končal študij. Takrat mu podjetje regresira plačilo šolnine in potrdi tudi druge ugodnosti.

Drugi razlog pa je $\mathrm{v}$ tem, da se posamezniki odločijo za študij, ki ni povezan $\mathrm{z}$ delom, ki ga opravljajo, niti z dejavnostjo podjetja. Če taki delavci zaprosijo za ugodnosti, lahko največkrat izrabijo le izredni plačani dopust za študij. Če pa se med šolanjem okoliščine spremenijo, pa lahko temu delavcu omogočimo tudi druge ugodnosti, večkrat mu tudi regresiramo plačilo šolnine.

- Le manjši del podjetij, zavodov ugotavlja potrebe in načrtuje izobraževanje zaposlenih (npr. s srednjo, višjo izobrazbo).

Študij ob delu je za delavce Krke že tradicija, saj je od leta 1956 do lanskega leta končalo študij že skoraj 900 zaposlenih. Osip ni bil velik, saj je končalo šolanje od 1356 kar 78,3 odstotka delavcev.

Zanimanje in potrebo po pridobitvi višje izobrazbe je opaziti med delavci $\mathrm{z}$ nižjo in $\mathrm{z}$ najvišjo izobrazbo.

V zadnjih 13 letih smo morali na zahtevo vodstva proizvodnje zdravil prekvalificirati 511 delavcev v poklice opravljalec farmacevtskih oziroma kemijskih naprav (II) in farmacevtski procesničar (IV). Zanimanje za to vrsto izobraževanja je bilo zelo veliko, saj pridobitev poklica zaposlenim zagotavlja varno zaposlitev in večjo plačo. Tovrstno izobraževanje nas čaka tudi na drugih področjih. Pravkar se je začelo šolati 62 delavcev v dveh oddelkih za poklic opravljalec farmacevtskih naprav. 
Ker projekt razvoja kadrov vključuje predvsem skrb za razvoj visokostrokovnega kadra, je zanimiv podatek o študiju ob delu za to strukturo, saj je tudi ta rezultat načrtnega usmerjanja v izobraževanje.

Letos ugotavljamo precejšnje število udeležencev podiplomskega študija, in sicer 49 , za vpis, ki iz leta v leto narašča, pa je zainteresiranih še 14 kandidatov. Visoke zahteve v farmacevtski stroki pogojujejo tudi usmerjenost visokostrokovnega kadra $\mathrm{v}$ nadaljnje izobraževanje na področju farmacije in kemije in $\mathrm{v}$ zvezi z vodenjem. Tako je v Krki do konca leta 1995 končalo študij MBA osem zaposlenih, dva zaposlena sta še vpisana, dvanajst zaposlenih pa je vpisalo specialistični študij iz vodenja.

- Slabo povezovanje podjetij, zavodov pri ugotavljanju (skupnih) potreb, dejavnost njihovih združenj je usmerjena le na nekatera področja (npr. usposabljanje managerjev, učiteljev).

Ta trditev drži. V Sloveniji namreč ni določene institucije ali organa, ki bi bila pristojna za:

- pripravo dolgoročne projekcije potreb po določenem izobrazbenem profilu;

- povezavo z delodajalci, ki imajo enake ali podobne potrebe po diplomantih določenih profilov.

„Kadrovske« potrebe ugotavljajo (z anketami) le $\mathrm{v}$ večjih podjetith in samo za diplomante višje- in visokošolskega študija ne glede na to, ali so končali redni študij ali študii odraslih (zaposlenih).
Za farmacevtska podjetja so najpomembnejši (profili) poklici: farmacevtski tehnik (in na nižji poklicni stopnji: opravljalec farmacevtskih naprav in kemijskih naprav), inženir farmacije (medicinska biofarmacija za bolnišnice), diplomirani inženir farmacije in magister farmacije.

V Sloveniji delujeta dve približno enako veliki farmacevtski podjetji, Lek in Krka, in eno manjše podjetje Bayerpharma. V okviru Gospodarske zbornice Slovenije smo povezani $\mathrm{v}$ združenje za kemično in gumarsko industrijo Slovenije. Omenjeni poklici so pomembni tudi v lekarnah, ki so povezane $\mathrm{v}$ Lekarniški zbornici.

Zaradi zahtev zakonskih določil se lahko zdravila prodajajo lekarnam prek veledrogerij, ki prav tako potrebujejo zaposlene $\mathrm{z}$ enakimi poklici. V zvezi z distribucijo in prodajo zdravil se pojavljajo tudi tuja podjetja, ki imajo v Sloveniji svoja predstavništva. Del te dejavnosti poteka tudi $\mathrm{v}$ zasebnih podjetjih, ki jih pred letom 1991 skoraj ni bilo.

Poklic farmacevta spada $\mathrm{v}$ zdravstveno, in ne v gospodarsko dejavnost, kar pomeni, da določijo profil poklica in sprejmejo študijski program za najvišje stopnje izobraževanja le $\mathrm{v}$ zdravstvu, ne pa v gospodarstvu, čeprav je število zaposlenih diplomiranih inženirjev farmacije v industriji precejšnje.

Zakon o zdravilih, ki velja od 2. 3. 1996, je uvedel vrsto specializacij, ki jih morajo imeti delavci pri posameznih delih $\mathrm{v}$ proizvodnji, pri skladiščenju, distribuciji in prodaji zdravil.

Ni še jasno, kdo bo sprejemal vsebine specializacij in kje jih bodo opravljali, kdo bo imel pogoje za opravljanje specializacij ipd., čeprav bi moralo usposabljanje glede na zakonske zahteve in roke že intenzivno potekati.

Čeprav spada proizvodnja zdravil po šifri dejavnosti v gospodarstvo, čeprav se kažejo številne potrebe po kadrih s temeljno izobrazbo diplomirani inženir farmacije in s specializacijo in čeprav se večina odločitev $\mathrm{v}$ zvezi $\mathrm{z}$ načrtovanjem po kadrih, $\mathrm{z}$ vsebino šolskih programov na določenih stopnjah, $\mathrm{z}$ uvajanjem dopolnilnega izobraževanja ipd. praviloma sprejema v zdravstvu brez sodelovanja zainteresiranih predstavnikov iz gospodarstva, predlagamo, da se v prihodnje $\mathrm{v}$ organe, ki pripravljajo in odločajo o navedenem, ali v skupne organe, obvezno vključujejo tudi predstavniki iz gospodarstva.

- Zaradi težav, neugotovljenih potreb in slabih stikov imajo podjetja, zavodi majhen vpliv na izobraževalno ponudbo visokošolskih zavodov (večji je vpliv pri strokovnem izpopolnjevanju) in na študijske programe.

O vplivu na študijske programe rednega šolanja je bila beseda že v prejšnji točki.

Za Krko pa bi bila zelo pomembna pomoč univerz oziroma fakultet pri oblikovanju in določanju vsebin za strokovno izpopolnjevanje in pri njihovi izvedbi.

Kaj bi nam olajšalo delo? Kakšno pomoč pričakujemo od visokošolskih zavodov? 
V veliko pomoč nam bi bilo sodelovanje strokovnjakov s fakultet, ki bi nam pomagali:

- izdelati analizo dejanskega znanja kandidatov za izpópolnjevanje kemije;

- izdelati analizo potrebnega znanja udeležencev;

- ugotoviti razliko v vsebini znanja;

- določiti vsebino izpopolnjevanja znanja ter

- oblike in metode za izpopolnjevanje znanja, kar bi premostilo to razliko;

- določiti predavatelje.

Večkrat se namreč zgodi, da zelo dobro določimo znanje, ki bi ga morala pridobiti določena skupina udeležencev izobraževanja, to tudi prenesemo na izbranega predavatelja (po možnosti $\mathrm{z}$ dobrimi priporočili), med izobraževanjem in po njem pa ugotavljamo, da je predaval udeležencem povsem standardno, ne da bi prilagodil vsebino udeležencem, upošteval podatke o podjetju, vključil strokovnjake iz podjetja, ki bolje poznajo posamezno temo od njega ipd.

Ugotavljamo, da je treba v zvezi z izobraževanjem $v$ Krki nujno uporabiti primere iz prakse, kar pa je za nekatere predavatelje očitno težko. Zelo dobro je, če predavajo predavatelji iz Krke in s fakultete. Pa ne le za udeležence, temveč tudi za predavatelje. Predavatelji iz prakse svoje znanje prenesejo tudi na predavatelje $s$ fakultete in nasprotno, predavatelji s fakultet obogatijo znanje praktikov $\mathrm{z}$ najnovejšimi teoretičnimi izhodišči.

Udeleženci izobraževanja iz Krke so običajno med najbolj razgledanimi in $s$ precejšnjim predhodnim znanjem, zato so do predavateljev in organizatorjev zelo zahtevni.

- Težave pri pripravi novih študijskih programov in visokošolskih zavodov ter zagotavljanju možnosti za njihovo izvajanje.

Naša proizvodnja je že pred šolsko reformo zahtevala, naj Fakulteta za farmacijo organizira višješolski strokovni študij farmacije ob delu, katerega program bi bil naravnan na kadre za delo v proizvodnji, vendar do priprave in potrditve takega študijskega programa ni prišlo.

Med pripravo reforme šolskega sistema (začetek leta 1994) pa je bil organiziran poseben posvet v Portorožu, na katerem je Fakulteta za farmacijo predstavila osnutek visokostrokovnega programa farmacije, vendar ga do letos še niso uvedli.

Na izrecno vztrajanje Krke je dekan Fakultete za farmacijo zagotovil, da je 3-letni strokovni program farmacevtske tehnologije $\mathrm{v}$ končni fazi in da ga bomo prejeli v presojo, v Krki pa smo medtem tudi natančno preverili, pri katerih delih bomo $\mathrm{v}$ prihodnosti potrebovali delavce takega profila, predvsem pa nam je jasno, da tovrstnega študija ni mogoče organizirati kot študij ob delu.

Tako bomo na začetku $\mathrm{v}$ tovrstni redni študij usmerjali dijake, ki so naredili zaključni izpit.

Pri tem je pomembno poudariti, da smo se $\mathrm{v}$ istem obdobju, ko Fakulteta za farmacijo ni mogla ustreči našim zahtevam po organizaciji višješolskega študija farmacevtske tehnologije, odločili, da preusmerimo zainteresirane farmacevtske in kemijske tehnike $\mathrm{v}$ študij na Fakulteti za organizacijske vede. Skupina iz Krke šteje 31 delavcev, ki končujejo študij. $\mathrm{Za}$ nas ne bodo imeli najustreznejše izobrazbe, vendar smo ocenili, da srednješolsko znanje farmacevtskega ali kemijskega tehnika, nakajletna pra-

Sodelovanje teoretikov in praktikov obogati znanje obeh. ksa v Krki in končana višja šola za organizacijo dela večinoma zadovoljujejo zahteve po znanju in izkušnjah, ki jih mora imeti delavec na težavnejših delih organiziranja dela $\mathrm{v}$ proizvodnji, logistiki ipd.

- Slabo sodelovanje pri izrednem študiju zaposlenih (npr. pri izbiri tem za seminarske, diplomske naloge), zlasti pri »ilegalnih« samoplačnikih.

$\mathrm{S}$ štipendisti in z vsemi, ki študirajo ob delu, sklenemo pogodbo o obveznostih in pravicah Krke ter pravicah in obveznostih udeleženca izobraževanja. Eno izmed določil pogodbe je tudi priprava diplomskih nalog z določeno temo, ki jo predlagajo strokovnjaki iz Krke.

Pri tem ugotavljamo več koristi:

- študent se prej naveže na matično podjetje, med študijem, ko opravlja prakso na različnih delovnih področjih, tudi spoznava delo in se ob zaposlitvi lažje odloči, kje želi delati;

- študent ob delu lažje poveže teorijo in prakso;

- povezava mentorjev s fakultete in Krke;

- najboljši študentje $\mathrm{z}$ nalogami konkurirajo za Krkine nagrade. 
- Slabo organizirane, neusposobljene »kadrovske službe« oziroma »human management « mnogih podjetij, zavodov.

Načrtno skrb za razvoj in izobraževanje zaposlenih lahko uresničujemo, ker smo v kadrovsko-pravnem sektorju primerno organizirani, imamo ustrezno število strokovnih kadrov in pooblastila za strokovno delo, ki ga opravljamo.

"Human resource management « (HRM) pokrivajo kadrovska služba in Izobraževalni center, v projektni skupini Razvoj kadrov pa se strokovno povezujejo sodelavci kadrovske službe in Izobraževalnega centra. Delo v tej skupini je čedalje pomembnejše in obsežnejše. $\mathrm{V}$ sektorju imamo enega magistra, dvanajst zaposlenih $\mathrm{z}$ visokošolsko in šestnajst $\mathrm{z}$ višješolsko izobrazbo. Tudi za najpomembnejše službe našega sektorja velja načelo, da si bomo tudi v prihodnosti prizadevali za višjo izobrazbeno strukturo.

\section{PREDLOGII DELODAIALCEM}

- Ugotavljajte potrebe po izobraževanju (podjetja, zavoda, zaposlenih), in sicer zdajšnje potrebe in potrebe, ki se šele pojavljajo, in sestavite kadrovske in izobraževalne načrte kot pomemben del poslovnega načrta (strategije, vodilne »filozofije «) podjetja, zavoda.

Izobraževalna ponudba, ki jo vsako leto pripravi Izobraževalni center, je zelo raznolika glede na:

- različno strukturo zaposlenih (po starosti, spolu, trajanju zaposlitve);

- delovno področje (sedanje, prihodnje);

- vsebino dela (proizvodnja, vzdrževanje, marketing itd.);

- zahtevnost dela (razvoj, top management, executive management, neposredni izvajalci del in nalog);

- čas in trajanje izvedbe (upoštevanje prostega časa, vrste delovnega časa);

- metodo dela (mladi, odrasli, prvič ponovno vključeni v izobraževanje);

- kraj izvedbe (na delovnem mestu, v Izobraževalnem centru, v tujini);

- zahteve zakonodaje, tuji partnerji, inšpekcija, FDA. tovitev projektne skupine za razvoj (pravilo- ma) visokošolskih kadrov, ki za posameznike pripravi izobraževalne načrte. Ti so namenjeni pridobivanju in obnovi potrebnega znanja za delo, ki ga opravljajo oziroma za katero se $\mathrm{z}$ razvojnim načrtom pripravljajo, pridobivanju znanja v zvezi z organizacijo, vodenjem, osebnostno rastjo, medsebojnimi odnosi, komunikacijo, informatiko, znanjem jezikov ipd.

$\mathrm{Na}$ podlagi pogovora $\mathrm{z}$ vodstvom posameznega sektorja pred in med izvajanjem projekta za razvoj kadrov v sektorju predlaga projektna skupina za razvoj kadrov organizacijo posameznih oblik izpopolnjevanja znanja v sektorju, na primer za vodstvene, poklicne skupine, delavce, ki delajo na enakih delovnih področjih ipd.

$\mathrm{Na}$ podlagi analiz o uporabnosti oziroma pomanjkljivosti znanja, pridobljenega $\mathrm{v}$ rednih šolah, ki ga ugotavljajo posamezniki, predlagamo tudi organizacijo izpopolnjevanja strokovnega znanja za posamezna delovna področja.

Odstotek zaposlenih, vključenih v izobraževanje, se je dvignil s 16 odstotkov v letu 1986 na več kot 105 odstotkov v letu 1993, ugotavljamo tudi, da se je $\mathrm{v}$ zadnjih letih umiril na več kot 90 odstotkih. Če te podatke spremenimo v ure, ugotovimo, da je v letu 1993 vsak udeleženec namenil izobraževanju 24 ur, v letu 199442 ur, v letu 1995 pa že 48 ur. V te podatke sta vključena izpopolnjevanje znanja in študij ob delu.

Najbolj je zastopano učenje in izpopolnjevanje znanja v zvezi s stroko, sledijo tuji jeziki, vodenje, informatika in kakovost.

- Vlagajte denar v študij/izobraževanje zaposlenih! To bo najboljša naložba v razvoj.

Tudi ta trditev za Krko drži. Žal zdaj podatkov še ne zajemamo tako, da bi imeli tudi podatke o osebnih dohodkih delavcev za dneve, ko se izobražujejo. Vendar nam kljub temu podatki za prvo polletje 1996 povedo zadosti.

Če k stroškom izobraževanja, ki se vodijo v okviru indirektnih stroškov, dodamo še stroške izobraževalnega centra (stroški dela, dajatve, amortizacija) ter potne stroške $\mathrm{v}$ zvezi $\mathrm{z}$ izobraževanjem doma in $\mathrm{v}$ tujini, znašajo stroški izobraževanja v Krki 124.861.000 SIT ali 0,6 odstotka poslovnih prihodkov. Če bi ta podatek uporabili za celo leto, bi znašali 
stroški izobraževanja letos 250 milijonov tolarjev.

\begin{tabular}{|c|c|}
\hline 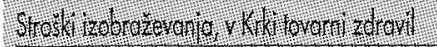 & Wisoenterorizy \\
\hline 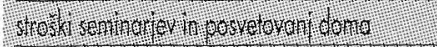 & $2 \sqrt{2 x}$ \\
\hline 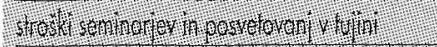 & 2) \\
\hline 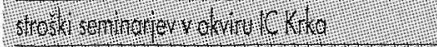 & Wo \\
\hline 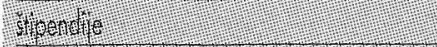 & 1) \\
\hline 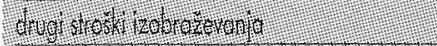 & 玨 \\
\hline 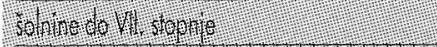 & So \\
\hline 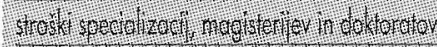 & (x) \\
\hline T., & $\sqrt{10}$ \\
\hline 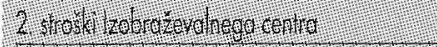 & $8 \times$ \\
\hline 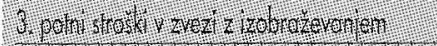 & Tho \\
\hline 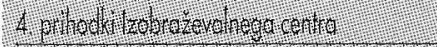 & \\
\hline $5.6 \times 1 \times 430$ & N) \\
\hline
\end{tabular}

- Plačujte šolnine in druge prispevke (ali vsaj dela) zaposlenim (tudi »tehnološkim presežkom $\ll$ ).

Znesek plačanih šolnin je znašal v letu 1995 1.950.000 SIT. Skoraj vse šolanje zaposlenih do V. stopnje izobrazbe, ki je do sedaj zajelo že več kot 511 delavcev, je bilo organizirano predvsem z namenom, da se v prihodnosti ne bi pojavljali tehnološki presežki. Razvoj tehnologije in predpisi inšpekcije namreč zahtevajo, da imajo v neposredni proizvodnji zaposleni najmanj II. stopnjo izobrazbe, to je farmacevtski oziroma kemijski opravljalec strojev. Če si delavci te izobrazbe ne bi pridobili, bi ostali brez dela oziroma bi lahko opravljali le najenostavnejša dela, ki pa jih v farmacevtski in kemijski proizvodnji skoraj ni več.

- Omogočite zaposlenim za študij/izobraževanje (za formalne in neformalne oblike) študijske dopuste in druge vrste odsotnosti!

Obseg odsotnosti z dela zaradi izobraževanja, kamor štejemo tudi študij ob delu, se vsako leto povečuje. Naš cilj je, da bi se vsak zaposleni vsako leto v povprečju izobraževal 10 dni.

- Poskrbite, da bo zagotovljen minimum pravic/obveznosti, ki je določen z zakoni in s kolektivnimi pogodbami! Poleg tega najnujnejšega omogočite tudi dodatne ugodnosti zaposlenim, ki študirajo!

Ugodnosti, ki jih predvidevajo predvsem kolektivne pogodbe, so zelo velike, zato smo nekatere v lastnem pravilniku o izobraževanju nekoliko priredili. Dodatnih ugodnosti pa ne omogočamo.
- Okrepite sodelovanje z drugimi partnerji v izobraževalnem sistemu (odraslih): visokošolskimi zavodi, državnimi organi, s sindikati, strokovnimi društvi!

Krka zelo dobro sodeluje na razvojnem področju predvsem s:

- Fakulteto za farmacijo,

- Fakulteto za kemijo in kemijsko tehnologi-

jo,

- Biotehniško fakulteto,

- Veterinarsko fakulteto.

Nekoliko manj pa sodeluje v zvezi z izobraževanjem.

Zato smo se ob obisku senata Fakultete za farmacijo iz Ljubljane v Krki dogovorili o načinih sodelovanja, da bi pridobili čim večje število kvalitetnih študentov, prihodnjih diplomantov oziroma delavcev:

1. skupno sodelovanje predstavnikov Fakultete za farmacijo in Krke na srednjih šolah pri predstavitvi študija, $v$ zvezi z delovnimi področji po diplomi, možnostmi štipendiranja in zaposlovanja (Gimnaziji Novo mesto, Bežigrad);

2. sofinanciranje videokasete ali (in) zloženke za prikaz študijskega programa in delovnih področij, na katerih se lahko diplomirani inženir farmacije zaposli po diplomi;

3. obisk študentov II. letnika v Krki - v sklopu predmeta farmacevtska tehnologija;

4. obisk absolventov Fakultete za farmacijo v Krki;

5. predavanja praktikov iz Krke na Fakulteti za farmacijo ali v Krki z ogledom posameznih delov Krke (sektor za raziskave in razvoj, sektor za upravljanje kakovosti, proizvodnja);

6. izdelava diplomskih nalog v Krki;

7. opravljanje obvezne strokovne prakse $\mathrm{v}$ Krki;

8. usmerjanje dobrih študentov v Krko (štipendiranje, Krkine nagrade, obvezna praksa, diplomske naloge);

9. organiziranje okroglih miz.

Uveljavite svoje interese v združenju zaposlovalcev (npr. Gospodarska zbornica, panožna združenja) zlasti pri oblikovanju novih programov, ustanavljanju novih visokošolskih zavodov in pri nadzoru nad kakovostjo študija/izobraževanja! 
- Pri ugotavljanju potreb po izobraževanju in načrtovanju (priprava metodologij, svetovanje, usposabljanje kadrovskih delavcev, konzultacije, ocena investicijskih načrtov itn.) poiščite strokovno pomoč institucij.

Ko smo pred leti v Krki uvajali razvoj kadrov, smo se obračali na fakultetne učitelje in strokovnjake s tega področja in jih prosili za pomoč. Žal je takrat nismo dobili, zato smo začeli sami, izdelali metodologijo razvoja kadrov in projekt tudi uresničili. Zelo smo zadovoljni, da je uspešen. Usposabljanja s svojega delovnega področja so deležni tudi sodelavci našega sektorja, čeprav v Sloveniji težko najdemo zadostno število seminarjev, na katerih bi udeleženci iz Krke dobili novo znanje. Zato se udeležujejo tudi seminarjev v tujini.

\section{NAMESTO SKLEPA}

1. Upravljanje $s$ človeškimi viri (HRM) bi moralo postati sestavni del upravljanja vsake gospodarske in negospodarske organizacije.

2. Vsak delodajalec bi moral izdelati projekcijo potreb po kadrih (poklicih) za daljše, vsaj srednjeročno, če ne dolgoročno obdobje.

3. Na podlagi dolgoročne projekcije potreb po kadrih bi lahko vsak delodajalec načrtno pripravljal kadrovske vire (štipendiranje, šolanje že zaposlenih ipd.).

4. Vsak delodajalec bi moral skrbeti za razvoj zaposlenih, tako da bi po posebni metodologiji izdelal za vsakega zaposlenega raz- vojni načrt (načrt poklicnega razvoja) in izobraževalni načrt za tri do pet let vnaprej.

5. Na podlagi izobraževalnih načrtov pa naj bi vsak delodajalec izdelal letni izobraževalni načrt za vse zaposlene.

6. Na državni ravni bi morala obstajati pristojna institucija, ki bi na podlagi ugotovljenih potreb načrtovala razvoj šolstva in uvajanje novih študijskih programov.

7. Za uresničitev nalog iz prejšnje točke bi se morale med seboj povezovati zbornice vseh delodajalcev.

8. Vsi visokošolski zavodi, ki izobražujejo strokovne delavce za delo v zvezi z upravljanjem s človeškimi viri, bi morali $v$ študijskih programih poglobljeno obravnavati razvoj kadrov.

9. V Sloveniji bi morali ustanoviti institucijo, ki bi spremljala razvoj upravljanja s človeškimi viri v svetu, svetovala in izobraževala strokovne delavce delodajalcev o tem, kakšne metode dela naj uporabljajo v zvezi z razvojem kadrov.

10. Strokovna združenja bi morala svoje člane seznanjati z najsodobnejšimi teoretičnimi izhodišči in jih usmerjati $\mathrm{v}$ najsodobnejšo prakso v zvezi z upravljanjem s človeškimi viri, ki jo uporabljajo v razvitem svetu.

11. Za delodajalce, ki imajo manj zaposlenih in zaposlujejo manj ljudi, bi morali organizirati pomoč pri pripravi kadrovskih in izobraževalnih načrtov za posameznika in organizacijo. 